\title{
Quality of Top, Middle and Bottom Buffelgrass Seeds From Different Collecting Sites
}

\author{
Sávio de Oliveira Ribeiro ${ }^{1}$, Maria Caroline Aguiar Amaral ${ }^{1}$, Welluma Teixeira Barros ${ }^{1}$, \\ Arlete da Silva Bandeira ${ }^{1}$, Adriana Dias Cardoso ${ }^{1} \&$ Ramon Correia de Vasconcelos ${ }^{1}$ \\ ${ }^{1}$ Department of Plant Science and Animal Science, State University of Southwest of Bahia, Vitória da Conquista, \\ BA, Brazil \\ Correspondence: Sávio de Oliveira Ribeiro, Department of Agricultural Engineering, Federal University of \\ Viçosa, University Campus, 36570-000, Viçosa, MG, Brazil. Tel: 55-779-8829-6353. E-mail: \\ savioor.agronomo@gmail.com
}

Received: February 21, 2019 Accepted: May 2, $2019 \quad$ Online Published: June 30, 2019

doi:10.5539/jas.v11n9p264 URL: https://doi.org/10.5539/jas.v11n9p264

\begin{abstract}
This work aimed to characterize physically and physiologically buffelgrass seeds collected in different municipalities located in the semiarid region of Bahia and at different positions in the panicle. At each site, two hundred mature, whole panicles were collected when seeds were naturally falling. A $5 \times 3$ factorial in a completely randomized design was used. Factors were five municipalities where seeds were collected and three positions within the panicle (bottom, middle and top portions), with four replicates of 50 seeds for each treatment Moisture content, dry seed weight, electrical conductivity, germination percentage, germination speed index and emergence speed index were assessed. Data were tested by analysis of variance and Tukey test at $5 \%$ of significance level. Soil and climate conditions of each region affect the physiological quality of buffelgrass seeds. Seeds located in bottom and middle portions of the panicle are more vigorous than seeds located in the top portion. The municipality of Poções has better conditions for yielding buffelgrass seeds of better quality than the remaining municipalities.
\end{abstract}

Keywords: Cenchrus ciliares L., germination, semiarid, vigor

\section{Introduction}

Buffelgrass (Cenchrus ciliares L.), a forage perennial grass belonging to the Poaceae family, is native to Africa and is widely grown across warm climates worldwide owing to its easy establishment, high nutritional value, and tolerance for drought, contributing to the reduction of nutritional deficiencies in livestock. Furthermore, its root system greatly deepens into the soil, being able to withstand heavy grazing and responds quickly to soil moisture (Miller, Friedel, Adam, \& Chewings, 2010; Voltolini, Moraes, Araújo, \& Pereira, 2011; Marshall, Lewis, \& Ostendorf, 2012; Lyons, Maldonado-Leal, \& Owen, 2013; Burson, Renganayaki, Dowling, Hinze, \& Jessup, 2015). Buffelgrass is generally used as a pastoral species and more recently for mine site rehabilitation and erosion control (Tefera et al., 2010; Guevara et al., 2009; Bhattarai, Fox, \& Gyasi-Agyei, 2008; Praveen et al., 2005; Harwood et al., 1999; Walker \& Weston, 1990).

The species was introduced to Brazil in São Paulo state, then, it was brought to northeastern states, where the semiarid climate predominates. There, it proved to be relevant due to its resistance to drought (Moreira, Lira, Santos, Araújo, \& Silva, 2007). Livestock farming is economically and socially important for the Brazilian semiarid, despite the fact that food availability to animals is limiting in this region, particularly in the dry season. Its native vegetation, Caatinga, is the main food source to livestock (Santos et al., 2011), in which buffelgrass stands out as the main forage grass cultivated in important ruminant-raising regions in the Brazilian semiarid (Oliveira et al., 2016).

This grass is suited to grow in disturbed areas, showing rapid growth and maturation, prolonged flowering and prolific seeding (Martin et al., 2015). Bufellgrass seeds have mechanisms of adaptation to adverse climatic conditions of semiarid regions, especially to low and irregular rainfall. This species, as well as most tropical forage grasses, does not exhibit its full genetic and physiological potential because of intrinsic factors such as seed dormancy. 
Buffelgrass is also one of the few forage species that is apomictic, that is, it can produce clones from seed, a trait that offers huge potential for the development and distribution of cultivars specifically suited to pastoral grazing (Akiyama et al., 2005; Ozias-Akins \& Van Dik, 2007). According to Whiteman and Mendra (1982), dormancy of tropical forage grasses is associated with physiological processes within freshly-harvested seeds, which is progressively suppressed during storage; or with physical features that are likely related to an outer cover restricting oxygen uptake by seeds.

Moreover, germination potential and vigor are influenced by the chemical compositions of the seed, which might be affected by the position of the seed within the inflorescence. The association between the onset of blooming, pollination season and prevailing climatic conditions during flower maturation has a direct impact on the uniformity of the process and on the chemical composition of the seed (Marcos Filho, 2005).

Alves and Kist (2011) investigated the quality of oat seeds as function of their positions within the panicle and reported a direct effect on seed quality, mainly when associated with seed weight, germination and vigor. Primary seeds, which are those located on primary branches of the panicle, exhibit higher physiological quality than secondary and tertiary seeds located on secondary and tertiary branches, respectively. Seed position also affects physiological quality of seeds of other species, as observed in maize plants (Mondo \& Cícero, 2005).

There are various parameters that are used to define seed quality. These include genetic, analytical purity, physiological, and pathological qualities (Scott \& Hampton, 1985). This components affect seeds' capacity of generating high-yielding plants. These seed properties have a direct impact on population uniformity, on seed-borne pests and diseases, and on vigor of plants (Popinigis, 1985).

Studies on germination and differentiation of physiological quality of buffelgrass seeds positioned at different locations of the panicle are lacking; therefore, this work aimed to carry out physical and physiological characterizations of buffelgrass seeds from different positions within the panicle of plants from the semiarid region of Bahia state, Brazil.

\section{Method}

Seeds were collected in February 2016 in rural properties of five municipalities in state of Bahia, Brazil: Anagé,

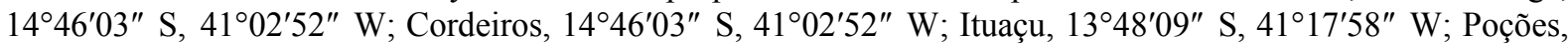
$14^{\circ} 26^{\prime} 03^{\prime \prime} \mathrm{S}, 40^{\circ} 21^{\prime} 10^{\prime \prime} \mathrm{W}$; and Tanhaçu, $14^{\circ} 09^{\prime} 42^{\prime \prime} \mathrm{S}, 41^{\circ} 12^{\prime} 11^{\prime \prime} \mathrm{W}$.

After collecting the seeds, they were taken to the Laboratory of Seed Technology and Production at the State University of Southeastern Bahia, campus Vitória da Conquista-Bahia, to test their physical and physiological quality.

A completely randomized design was used, in a $5 \times 3$ factorial experiment (five municipalities and three positions within the panicle; bottom, middle and top portions), with four replicates.

Two hundred mature, whole panicles were collected when grains were starting to naturally fall; then, seeds were sorted and separated according to their positions within the panicle (bottom, middle or top) at harvest.

Physical and physiological qualities of seeds were determined by the following tests:

Moisture content of seeds at harvest (MC): four subsamples containing 50 seeds in each replicate were dried in an oven at $105 \pm 3{ }^{\circ} \mathrm{C}$ over 24 hours, following the Rules of Seed Analysis (Brasil, 2009).

Dry seed weight (DSW): this test was conducted jointly with the moisture content test using the dry weight obtained at the end of it. Dry weight was divided by the number of seeds tested for moisture content and the results were expressed in grams.

Electrical conductivity test (EC): this test was carried out in accordance with the method proposed by AOSA (1983) and described by Marcos Filho and Vieira (2009), with 50 seeds in each replicate. Seeds were weighed and placed into $200-\mathrm{mL}$ plastic cups containing $75 \mathrm{~mL}$ of distilled water (Hamptom \& Tekrony, 1995), then, they were kept in a growth chamber for 24 hours at $25{ }^{\circ} \mathrm{C}$ (Loeffler, Tekrony, \& Egli, 1988). After this period, the electrical conductivity of the imbibition medium was read with the aid of an electrical conductivity meter (model Digimed) and the results were expressed as $\mu \mathrm{S} \mathrm{cm}^{-1} \mathrm{~g}^{-1}$ of seeds (Krzyzanowski, Vieira, \& França Neto, 1999).

Germination rate or percentage $(G)$ : germination tests were conducted without applying any treatment to overcome the physiological dormancy of seeds. Four replicates of 50 seeds each were used in each treatment. Germination test paper was soaked in distilled water equivalent to 2.5 times the weight of the dry substrate. Seeds were evenly distributed onto two sheets of paper inside gearbox-type boxes. Afterwards, boxes were covered with $0.0033-\mathrm{mm}$-thick plastic bags, which were closed to avoid dehydration and placed horizontally in a B.O.D. (Biochemical Oxygen Demand) at $25{ }^{\circ} \mathrm{C}$ in the dark. Normal and abnormal seedlings were counted to 
determine the germination percentage. Dormant, hard or dead seeds were also counted as standardized by the Rules of Seed Analysis (Brasil, 2009) and final results were expressed as a percentage.

Germination speed index (GSI): germinated seeds were counted on the $7^{\text {th }}, 14^{\text {th }}, 21^{\text {st }}, 28^{\text {th }}$ day after the beginning of the germination test, and GSI was calculated according to the formula described by Maguire (1962).

$$
\mathrm{GSI}=\mathrm{E} 1 / \mathrm{N} 1+\mathrm{E} 2 / \mathrm{N} 2+\ldots+\mathrm{En} / \mathrm{Nn}
$$

where,

$\mathrm{GSI}=$ germination speed index; E1, E2, .. En = number of normal seedlings at the first, second and last count, respectively; $\mathrm{N} 1, \mathrm{~N} 2, \ldots \mathrm{Nn}$ = number of days to first, second and last count, respectively.

Seeds were considered germinated when the primary root was emerged and the length of seedlings were equal to or longer than $2 \mathrm{~cm}$.

Emergence speed index (ESI): this test was carried out in a greenhouse with four subsamples of 50 seeds for each treatment. Metallic trays measuring $24 \times 17 \times 6 \mathrm{~cm}$ were used, to which washed sand was added as a substrate. Seeds were distributed on it and covered up by the same substrate. Substrate was watered whenever necessary using the same amount of water for every experimental unit. The test was done when the emergence of seedlings stabilized. Counting was standardized by considering the seedling as emerged when the primary leaves above ground surface were $1 \mathrm{~cm}$ long. Counts took place from the emergence of the first seedling. At the end of the test, ESI was calculated using the formula proposed by Maguire (1962).

$$
\mathrm{ESI}=\mathrm{E} 1 / \mathrm{N} 1+\mathrm{E} 2 / \mathrm{N} 2+\ldots+\mathrm{En} / \mathrm{Nn}
$$

where,

$\mathrm{ESI}=$ emergence speed index; E1, E2, .. En = number of normal seedlings at the first, second and last count, respectively; $\mathrm{N} 1, \mathrm{~N} 2, \ldots \mathrm{Nn}$ = number of days to first, second and last count, respectively.

Results were tested for normality by Lilliefors test and Cochran's $\mathrm{c}$ test. As for emergence speed index and seed dry weight tests, data were converted into $\sqrt{\mathrm{x}}$, so they would be considered normal. After, data were tested by analysis of variance and means were compared to one another by Tukey test at $5 \%$ of significance level using the statistical software ASSISTAT, version 7.7 (Silva, 2016).

\section{Results and Discussion}

There were statistical differences across treatments for all measured variables. Between factors, interactions were significant for moisture content, dry weight and electrical conductivity of seeds (Table 1).

Table 1. Summary of the analysis of variance and coefficients of variation of moisture content at harvest (MC), seed dry weight (SDW), electrical conductivity (EC), germination percentage (GER), germination speed index (GSI) and emergence speed index (ESI) of buffelgrass seeds from municipalities in the semiarid of Bahia and from different positions within the panicle

\begin{tabular}{llllllll}
\hline \multirow{2}{*}{ SV } & \multirow{2}{*}{ DF } & \multicolumn{5}{c}{ Mean squares } \\
\cline { 3 - 7 } & & MC & SDW $^{1}$ & EC & GER $^{1}$ & GSI $^{1}$ & ESI \\
\hline Municipality (M) & 4 & $29.30^{*}$ & $0.005^{*}$ & $22,035.91^{*}$ & $5.78^{*}$ & $0.39^{*}$ & $1.33^{*}$ \\
Position (P) & 2 & $9.52^{*}$ & $0.072^{*}$ & $19,212.42^{*}$ & $7.18^{*}$ & $0.57^{*}$ & $0.71^{*}$ \\
M x P & 8 & $3.33^{*}$ & $0.0005^{*}$ & $2,534.83^{*}$ & 0.40 & 0.03 & 0.18 \\
Residue & 45 & 0.54 & 0.0001 & 571.34 & 0.51 & 0.03 & 0.21 \\
\hdashline CV (\%) & & 8.57 & 3.34 & 6.48 & 20.17 & 21.29 & 21.26 \\
\hline
\end{tabular}

Note. ${ }^{1}$ Data converted into $\sqrt{\mathrm{x}} ;{ }^{*}$ Significant at $5 \%$ of significance level by $\mathrm{F}$ test. 
Table 2. Moisture content (\%) of buffelgrass seeds as a function of the harvest in municipalities located in semiarid regions of Bahia and of the seed position in the panicle

\begin{tabular}{llll}
\hline \multirow{2}{*}{ Municipalities } & \multicolumn{3}{c}{ Position in the panicle } \\
\cline { 2 - 4 } & Top & Middle & Bottom \\
\hline Cordeiros & $8.88 \mathrm{Aab}$ & $8.72 \mathrm{Aab}$ & $9.26 \mathrm{Ab}$ \\
Ituaçu & $10.06 \mathrm{Ba}$ & $9.58 \mathrm{Ba}$ & $11.42 \mathrm{Aa}$ \\
Anagé & $8.13 \mathrm{Bbc}$ & $8.77 \mathrm{Bab}$ & $12.12 \mathrm{Aa}$ \\
Poções & $7.09 \mathrm{Acd}$ & $7.53 \mathrm{Abc}$ & $7.56 \mathrm{Ac}$ \\
Tanhaçu & $6.35 \mathrm{Ad}$ & $6.90 \mathrm{Ac}$ & $6.57 \mathrm{Ac}$ \\
\hline CV $(\%)$ & 8.57 & & \\
\hline
\end{tabular}

Note. Means followed by the same lowercase letter in the columns and uppercase letters in the rows do not differ statistically from one another by Tukey test at $5 \%$ of significance level.

When measuring moisture content of seeds at different positions in the panicle, it was verified that seeds from the top portion of the panicle harvested in Ituaçu were similar to seeds harvested in Cordeiros and higher than those from the remaining municipalities. Seeds collected in Anagé had higher moisture content in comparison with seeds collected in Poções and Tanhaçu (Table 2). Seed moisture content is directly related to its physiological quality since it interferes with storage and commercialization, with germination and, consequently, with seed vigor.

As for seeds from the middle portion of the panicle, the highest seed moisture contents were observed in those from Cordeiros, Ituaçu and Anagé in relation to those collected in Tanhaçu (Table 2). As for seeds harvested at the bottom portion of the panicle, it was observed that seeds from Ituaçu and Anagé had higher moisture contents than those from the remaining municipalities. Seeds from Poções and Tanhaçu had lower moisture content (Table 2). This difference in moisture contents might be due to how and how long the pasture had been used, and to soil nutrition, texture and structure, which all interfere with the plant's nutritional status. Moreover, climatic elements such as temperature and rainfall, as well as genetic variability of seeds from each collecting site, had also an influence on it.

When evaluating seed dry weight, interactions show that bottom seeds had higher means regardless of the municipality where they were harvested. Top seeds had lower means than the remaining seed positions in the panicle (Table 3). Top seeds from Anagé and Poções stood out from those harvested in Cordeiros and Ituaçu.

Table 3. Dry weight (g) of buffelgrass seeds as a function of the harvest in municipalities located in semiarid regions of Bahia and of the seed position in the panicle

\begin{tabular}{llll}
\hline \multirow{2}{*}{ Municipality } & \multicolumn{3}{c}{ Position in the panicle } \\
\cline { 2 - 4 } & Top & Middle & Bottom \\
\hline Cordeiros & $0.27 \mathrm{Cb}(0.07)$ & $0.33 \mathrm{Bd}(0.11)$ & $0.37 \mathrm{Acc}(0.14)$ \\
Ituaçu & $0.27 \mathrm{Cb}(0.07)$ & $0.35 \mathrm{Bbc}(0.12)$ & $0.40 \mathrm{Ab}(0.16)$ \\
Anagé & $0.30 \mathrm{Ca}(0.09)$ & $0.38 \mathrm{Ba}(0.14)$ & $0.44 \mathrm{Aa}(0.20)$ \\
Poções & $0.30 \mathrm{Ca}(0.09)$ & $0.37 \mathrm{Bab}(0.13)$ & $0.42 \mathrm{Aab}(0.18)$ \\
Tanhaçu & $0.28 \mathrm{Cab}(0.08)$ & $0.35 \mathrm{Bcd}(0.12)$ & $0.38 \mathrm{Ac}(0.14)$ \\
CV $(\%)$ & $3.34(6.81)$ & & \\
\hline
\end{tabular}

Note. Data converted into $\sqrt{\mathrm{x}}$; means without conversion are between parenthesis.

Means followed by the same lowercase letter in the columns and uppercase letter in the rows do not differ from one another by Tukey test at $5 \%$ of significance level.

Seeds at the middle portion of the panicle collected in Anagé had the same weight than those collected in Poções and were heavier than those from the remaining municipalities. The lightest seeds were collected in Cordeiros. As for bottom seeds, those from Anagé and Poções were the heaviest and those collected in Cordeiros and Tanhaçu, the lightest. According to Carvalho and Nakagawa (2000), this characteristic has been considered the main physiological maturity index in orthodox seeds as the maximum accumulation of biomass is reported at the point of seed maturation. Mohammed and Tarpley (2011) affirmed that there is competition for photoassimilates among seeds located at different positions in the inflorescence, which explains the results reported herein. 
Electrical conductivity of bottom seeds collected in Cordeiro and Poções exhibited higher membrane integrity (Table 4). In Ituaçu, bottom seeds had higher integrity than seeds at the top of the panicle. In Anagé, higher integrity was observed in bottom seeds while lower integrity in top seeds. At last, in Tanhaçu, seeds at the middle portion of the panicle exhibited lower electrical conductivity and, therefore, they had higher membrane integrity.

Table 4. Electrical conductivity $\left(\mu \mathrm{S} \mathrm{cm}^{-1} \mathrm{~g}^{-1}\right)$ of buffelgrass seeds as a function of the harvest in municipalities located in semiarid regions of Bahia and of seed position in the panicle

\begin{tabular}{llll}
\hline \multirow{2}{*}{ Municipality } & \multicolumn{3}{c}{ Position in the panicle } \\
\cline { 2 - 4 } & Top & Middle & Bottom \\
\hline Cordeiros & $432.01 \mathrm{Aa}$ & $425.09 \mathrm{Aa}$ & $359.45 \mathrm{Bb}$ \\
Ituaçu & $401.06 \mathrm{Aa}$ & $360.20 \mathrm{ABbc}$ & $333.82 \mathrm{Bb}$ \\
Anagé & $403.76 \mathrm{Aa}$ & $359.44 \mathrm{Bbc}$ & $313.69 \mathrm{Cb}$ \\
Poções & $337.05 \mathrm{Ab}$ & $321.30 \mathrm{Ac}$ & $255.37 \mathrm{Bc}$ \\
Tanhaçu & $425.01 \mathrm{Aa}$ & $380.66 \mathrm{Bab}$ & $426.64 \mathrm{Aa}$ \\
\hline CV $(\%)$ & 6.48 & & \\
\hline
\end{tabular}

Note. Means followed by the same letter, lowercase in the columns and uppercase in the rows, do not differ from one another by Tukey test at $5 \%$ of significance.

Seeds collected from the top portion of the panicle of plants from Poções had the lowest electrical conductivity, i.e., lower electrolyte efflux out the seed, which indicates higher membrane integrity. Seeds collected from the middle portion of the panicle of plants from Cordeiros had the lowest membrane integrity. As for bottom seeds, those from Poções had the highest integrity and those from Tanhaçu, the least.

Milošević et al. (2010) reported that the faster the seed can reestablish the integrity of cell membranes, the less electrolyte leaches from it; thus, seeds with higher electrical conductivity in the imbibition medium have more permeable membranes, which results in seed deterioration, that is, lower vigor.

Germination percentage of seeds from Poções was higher than those from the remaining municipalities. In regard to seed position within the panicle, seeds located in the middle and bottom portion germinated more than seeds in the top portion of the panicle (Table 5). Santos et al. (2013) found higher germination rates than the ones reported herein when buffelgrass seeds were subjected to different temperatures, especially to $25{ }^{\circ} \mathrm{C}$, which was the same temperature used in this work. This temperature is more efficient for seed germination, whose average ranges from $20 \%$ to $50 \%$. Alves and Kist (2011) reported that oat seeds from primary branches had higher performance as to weight, germination and vigor than seeds from secondary and tertiary branches.

Table 5. Germination percentage (GER) and germination speed index (GSI) of seeds and emergence speed index (ESI) of seedlings of buffelgrass as a function of the harvest in different municipalities in the semiarid regions of Bahia and of position within the panicle

\begin{tabular}{llll}
\hline Municipality & GER* & GSI* & ESI \\
\hline Cordeiros & $3.39 \mathrm{~b}(11.96)$ & $0.83 \mathrm{~b}(0.73)$ & $1.94 \mathrm{~b}$ \\
Ituaçu & $2.81 \mathrm{~b}(8.46)$ & $0.72 \mathrm{~b}(0.56)$ & $2.01 \mathrm{~b}$ \\
Anagé & $3.62 \mathrm{~b}(14.17)$ & $0.88 \mathrm{~b}(0.84)$ & $1.82 \mathrm{~b}$ \\
Poções & $4.68 \mathrm{a}(22.71)$ & $1.20 \mathrm{a}(1.48)$ & $2.65 \mathrm{a}$ \\
Tanhaçu & $3.28 \mathrm{~b}(11.33)$ & $0.83 \mathrm{~b}(0.72)$ & $2.30 \mathrm{ab}$ \\
\hline Position in the panicle & \% GERM* & GSI* & ESI \\
\hline Top & $2.87 \mathrm{~b}(8.80)$ & $0.69 \mathrm{~b}(0.52)$ & $1.96 \mathrm{~b}$ \\
Middle & $3.93 \mathrm{a}(16.22)$ & $0.99 \mathrm{a}(1.05)$ & $2.14 \mathrm{ab}$ \\
Bottom & $3.88 \mathrm{a}(16.15)$ & $0.98 \mathrm{a}(1.03)$ & $2.33 \mathrm{a}$ \\
\hline CV $(\%)$ & $20.17(40.08)$ & $21.29(42.52)$ & 21.26 \\
\hline
\end{tabular}

Note. Means followed by the same letter in the column do not differ from one another by Tukey test at $5 \%$ of significance level. *For testing, data were converted into $\sqrt{\mathrm{x}}$. Data without conversion are in parenthesis.

Lopes (2009) reported that the lowest germination rate required for buffelgrass seeds is $30 \%$. All germination percentages presented herein were lower than the minimum required by the law. Tinoco-Ojanguren et al. (2016) 
observed that some seeds did not germinate even after the removal of the protective structures, and gibberellin-treated seeds did not germinate either, suggesting that buffelgrass seeds are physiologically dormant. González-Rabanal, Casal, and Trabaud (1994) studied three Spanish grasses and found lower germination rates of seeds located at the apex of the panicles than those at the basal portion.

Seed bank longevity ranges from two to thirty years (Friedel et al., 2007). However, Winkworth (1963) reported a decrease in germination from the eighth month after sowing and stored seeds showed a $94 \%$ increase in germination in the period from eight to eighteen months.

Seeds collected in Poções exhibited the highest germination speed index. Seeds in the top portion of panicles germinated the slowest (Table 5). This is probably because of the position of seeds within the panicle in relation to the amount of nutrients exported to them, i.e., the proximity of fertilized ovules to the nutrient source; thus, seeds located closer to the bottom of the panicle tend to absorb more nutrients than the remaining seeds in the panicle. Seed position can decrease the flow of reserves from one seed to another. Cherobini, Muniz and Blume (2008) observed that germination speed index of Cedrela fissilis Vell. was influenced by the seeds' origins, as verified in this study.

As for emergence speed index, Poções and Tanhaçu had similar averages, both of which were superior to the remaining municipalities. GSI test showed that bottom seeds emerged faster than top seeds, which is probably due to the competition for nutrients that affects both germination and emergence. Field-grown seedlings from seeds collected in Poções and Tanhaçu had equal average averages for emergence speed index (ESI) and were higher than the remaining municipalities (Table 5).

Wang, Tan, C. C. Baskin, and J. M. Baskin (2010) found results similar to the results of this study for the emergency test of the specie Eremopyrum distans (K. Koch) Nevski. The authors observed that seeds from the top portion of the inflorescence obtained lower percentages of emergence in relation to seeds of the median and basal portion.

\section{Conclusion}

The findings of this study indicate that soil and climate conditions influence the physiological quality of buffelgrass seeds from the semiarid regions of Bahia state, Brazil. Seeds from the bottom and middle portions of the panicle are more vigorous than seeds from the top portion as to every assessed characteristic. The municipality of Poções has better conditions for yielding buffelgrass seeds of better quality than in the remaining municipalities.

\section{References}

Akiyama, Y., Hanna, W., \& Ozias-Akins, P. (2005). High-resolution physical mapping reveals that the apospory-specific genomic region (ASGR) in Cenchrus ciliaris is located on a heterochromatic and hemizygous region of a single chromosome. Theoretical and Applied Genetics, 111, 1042-1051. https://doi.org/10.1007/s00122-005-0020-5

Alves, A. C., \& Kist, V. (2011). Qualidade fisiológica de sementes primárias, secundárias e terciárias da espigueta de aveia branca (Avena sativa L.). Current Agricultural Science and Technology, 17(1), 153-157.

AOSA (Association of Official Seed Analysis). (1983). Seed vigor testing handbook (p. 88). East Lasing, AOSA.

Bhattarai, S. P., Fox, J., \& Gyasi-Agyei, Y. (2008). Enhancing buffel grass seed germination by acid treatment for rapid vegetation establishment on railway batters. Journal of Arid Environments, 72, 255-262. https://doi.org/10.1016/j.jaridenv.2007.06.010

Brasil, Ministério da Agricultura, Pecuária e Abastecimento. (2009). Regras para análise de sementes (p. 399). Secretaria de Defesa Agropecuária. Brasília: Mapa/ACS.

Burson, B. L., Renganayaki, K., Dowling, C. D., Hinze, L. L., \& Jessup, R. W. (2015). Genetic diversity among pentaploid buffel grass accessions. Crop Science, 55(4), 1637-1645. https://doi.org/10.2135/cropsci2014. 09.0655

Carvalho, N. M., \& Nakagawa, J. (2000). Sementes: Ciência, tecnologia e produção (p. 588). Jaboticabal: FUNEP. https://doi.org/10.17801/0101-3122/rbs.v22n1p185-192

Cherobini, E. A. I., Muniz, M. F. B., \& Blume, E. (2008). Avaliação da qualidade de sementes e mudas de cedro. Ciência Florestal, 8(1), 65-73. https://doi.org/10.5902/19805098511

Friedel, M., Bastin, G., Brock, C., Butler, D. W., Clarke, A., Eyre, T. J., ... Smyth, A. (2007). Developing a research agenda for the distribution and rate of spread of buffel grass (Cenchrus ciliaris) and identifi 
cation of landscapes and biodiversity assets at most risk from invasion. Report to the Department of Environment and Water: Canberra, Australia.

González-Rabanal, F., Casal, M., \& Trabaud, L. (1994). Effects of high temperatures, ash and seed position in theinflorescence on the germination of three Spanish grasses. Journal of Vegetation Science, 5, $289-294$. https://doi.org/10.2307/3235851

Guevara, J. C., Grunwaldt, E. G., Estevez, O. R., Bisigato, A. J., Blanco, L. J., Biurrun, F. N., ... Passera, C. B. (2009). Range and livestock production in the Monte Desert, Argentina. Journal of Arid Environments, 73, 228-237. https://doi.org/10.1016/j.jaridenv.2008.02.001

Harwood, M. R., Hacker, J. B., \& Mott, J. J. (1999). Field evaluation of seven grasses for use in the revegetation of lands disturbed by coal mining in Central Queensland. Australian Journal of Experimental Agriculture, 39, 307-316. https://doi.org/10.1071/EA98119

Hampton, J. G., \& Tekrony, D. M. (1995). Handbook of vigour test methods. The International Seed Testing Association, Zurich, Switzerland.

Krzyzanowski, F. C., Vieira, R. D., \& França neto, J. B. (1999). Vigor de sementes: conceitos e testes. Londrina, PR, Brazil.

Lyons, K. G., Maldonado-Leal, B. G., \& Owen, G. (2013). Community and ecosystem effects of buffelgrass (Pennisetum ciliare) and nitrogen addition in the Sonoran desert. Invasive Plant Science and Management, 6, 65-78. https://doi.org/10.1614/IPSM-D-11-00071.1

Loeffler, T. M., Tekrony, D. M., \& Egli, D. B. (1988). The bulk conductivity test as an indicator of soybean seed quality. Journal of Seed Technology, 37-53.

Maguire, J. D. (1962). Speed of germination-aid seedling emergence and vigor. Crop Science, 2(2), $176-177$. https://doi.org/10.2135/cropsci1962.0011183X000200020033x

Marcos Filho, J. (2005). Fisiologia de sementes de plantas cultivadas (p. 495). Piracicaba: FEALQ.

Marcos Filho, J., \& Vieira, R. D. (2009). Seed vigor tests: Procedures-conductivity tests. In R. Baalbaki (Ed.), Seed vigor tests handbook (pp. 186-200). Ithaca, New York, USA: AOSA

Martin, T. G., Murphy, H., Liedloff, A., Thomas, C., Chadès, I., Cook, G., ... van Klinken, R. D. (2015). Buffel grass and climate change: A framework for projecting invasive species distributions when data are scarce. Biological Invasions, 17(11), 3197-3210. https://doi.org/10.1007/s10530-015-0945-9

Marshall, V. M., Lewis, M. M., \& Ostendorf, B. (2012). Buffel grass (Cenchrus ciliaris) as an invader and threat to biodiversity in arid environments: A review. Journal of Arid Environments, 78, 1-12. https://doi.org/ 10.1016/j.jaridenv.2011.11.005

Miller, G., Friedel M., Adam P., \& Chewings V. (2010). Ecological impacts of buffel grass (Cenchrus ciliaris L.) invasion in central Australia-does field evidence support a fire-invasion feedback? The Rangeland Journal, 32, 353-65. https://doi.org/10.1071/RJ09076

Milošević, M., Vujaković, M. E., \& Karagić, Đ. (2010). Vigour tests as indicators of seed viability. Genetika, 42(1), 103-118. https://doi.org/10.2298/GENSR1001103M

Mohammed, A. R., \& Tarpley, L. (2011). Effects of night temperature, spikelet position and salicylic acid on yield and yield - related parameters of rice (Oryza sativa L.) plants. Journal of Agronomy and Crop Science, 197(1), 40-49. https://doi.org/10.1111/j.1439-037X.2010.00439.x

Mondo, V. H. V., \& Cìcero, S. M. (2005). Análise de imagens na avaliação da qualidade de sementes de milho localizadas em diferentes posições na espiga. Revista Brasileira de sementes, 27(1), 09-18. https://doi.org/10.1590/S0101-31222005000100002

Moreira, J. N., Lira, M. A., Santos, M. V. F., Araújo, G. G. L., \& Silva, G. C. (2007). Potencial de Produção de Capim buffel na época seca no Semiárido Pernambucano. Revista Caatinga, 20(3), 22-29.

Oliveira, R. G. D., Voltolini, T. V., Mistura, C., Moraes, S. A. D., Souza, R. A., \& Santos, B. R. C. D. (2016). Desempenho produtivo e características de carcaça de ovinos mantidos em pastos de duas cultivares de capim-bufel manejados em três ofertas de forragem. Revista Brasileira de Saúde e Produção Animal, 17(3), 1519-9940. https://doi.org/10.1590/S1519-99402016000300005

Praveen, K., Kumar, S., Sharma, K. D., Choudhary, A., \& Gehlot, K. (2005). Lignite mine spoil characterization and approaches for its rehabilitation. Arid Land Research and Management, 19, 47-60. https://doi.org/ 


\section{$10.1080 / 15324980590887218$}

Santos, R. M., Voltolini, T. V., Angelotti, F., \& Dantas, B. F. (2013). Germinação de sementes de capim-buffel em diferentes temperaturas. Pangeia Cientifica, 1(1), 11-16.

Santos, P. M., Voltolini, T. V., Cavalcante, A. C. R., Pezzopane, J. R. M., Moura, M. S. B. de., Silva, T. G. F. da \& Bettiol, G. M. (2011). Mudanças climáticas globais e a pecuária: Cenários futuros para o Semiárido brasileiro. Revista Brasileira de Geografia Física, 4(1), 1176-1196. https://doi.org/10.26848/rbgf.v4i6. 232765

Scott, D. J., \& Hampton, J. G. (1985). Aspects of seed quality. Producing herbage seeds. Grasslands Research and Practice Series, 2, 43-52.

Silva, F. A. S. (2016). ASSISTAT: Versão 7.7 Beta. DEAG-CTRN-UFCG. Retrived from http://www.assistat. com.br

Tefera, S., Dlamini, B. J., \& Dlamini, A. M. (2010). Changes in soil characteristics and grass layer condition in relation to land management systems in the semi-arid savannas of Swaziland. Journal of Arid Environments, 74, 675-684. https://doi.org/10.1016/j.jaridenv.2009.10.016

Tinoco-Ojanguren, C., Reyes-Ortega, I., Sánchez-Coronado, M. E., Molina-Freaner, F., \& Orozco-Segovia, A. (2016). Germination of an invasive Cenchrus ciliaris L. (buffel grass) population of the Sonoran Desert under various environmental conditions. South African Journal of Botany, 104, 112-117. https://doi.org/10.1016/ j.sajb.2015.10.009

Voltolini, T. V., Moraes, S. A., Araújo. G. G. L., \& Pereira, L. G. R. (2011). Concentrate levels for lambs grazing on Buffel grass. Revista Ciência Agronômica, 42(1), 216-222. https://doi.org/10.1590/S1806-66902011 000100027

Walker, B., \& Weston, E. J. (1990). Pasture development in Queensland e a success story. Tropical Grasslands, 24, 257-268.

Wang, A. B., Tan, D. Y., Baskin, C. C., \& Baskin, J. M. (2010). Effect of seed position in spikelet on life history of Eremopyrum distans (Poaceae) from the cold desert of north-west China. Annals of Botany, 106(1), 95-105. https://doi.org/10.1093/aob/mcq089

Whiteman, P. C., \& Mendra, K. (1982). Effects of storage and seed treatments on germination of Brachiaria decumbens. Seed Science and Technology, 10(2), 233-242.

Winkworth, R. (1963). The germination of buffel grass (Cenchrus ciliaris) seed after burial in a Central Australian soil. Australian Journal of Experimental Agriculture and Animal Husbandry, 3(11), 326-328. https://doi.org/ 10.1071/EA9630326

\section{Copyrights}

Copyright for this article is retained by the author(s), with first publication rights granted to the journal.

This is an open-access article distributed under the terms and conditions of the Creative Commons Attribution license (http://creativecommons.org/licenses/by/4.0/). 